wing. Abdomen broad, about double the width of the thorax, the five segments shining, sparsely covered with whitish hairs. Halteres white, base of the knobs and stems brown. Legs black, knees, tips of the tibiæ and the tarsi yellow, the last two joints of the latter brownish. Wings hyaline, veins yellowish, three veins extending from the discal cell. Length, $4 \mathrm{~mm}$.

One specimen, collected along Austen's Brook, Chester, Mass., May 28, 1912. Type in the collection of the Boston Society of Natural History.

Other interesting Stratiomyidæ collected at Chester, Mass., are Scoliopelta luteipes Will. (Entom. Amer., I, 154, 1885) which was quite common August 5 and 6, 1914, and a specimen of Chrysochroma nigricornis Loew, July 25, 1913.

\title{
A NEW AËDINE.
}

By C. S. Ludlow, Army Medical Museum, Washington, D. C.

A long while ago, before it was known that Skusea multiplex Theob. had long palpi in the male, and therefore was not a Skusea, I received and named a lot of mosquitoes, which seemed to be of this species. Nothing had called my attention to the change of position of multiplex, so the specimens were not re-examined, but lately I sent specimens to Mr. Edwards, who has called my attention to this point and, as the species was undescribed, kindly returned the specimens for description. In general appearance the female probably more nearly resembles multiplex than any other species but it is described below as

Aëdes panayensis sp. nov.

Head dark brown, covered with flat brown scales, which appear grey in some lights, and small curved scales around the eyes; antennæ brown, white-banded, verticels brown, pubescence white; palpi brown and very short in both male and female; proboscis brown; clypeus brown; eyes dark brown.

Prothoracic lobes brown; mesothorax brown, sometimes very dark, and covered with slender golden brown curved scales; scutellum as mesothorax, with six long marginal brown bristles on the mid, and three marginal bristles on the lateral lobes; pleura dark, with bunches of white scales; metanotum dark brown.

Abdomen with brown scales and large white basal lateral spots on all but the eighth segment.

Legs: coxæ and trochanters light; femora dorsally brown, and ventrally white nearly to the apex, and a light knee spot; tibiæ dorsally brown, darker than the 
femora, but ventrally white scaled to the apex; tarsal joints all brown. With the exception of the femora, all the parts of the legs show a decided variation as to color, dependent on the angle of light. Ungues of female serrate, those of the male fore legs have both the ungues serrate.

Wing clear, covered with brown rather heavy Taniorhynchus-like scales. The first sub-marginal cell is about three times as long as its stem, and nearly a third longer and as wide as the second posterior cell, which is about the same length as its stem. The mid cross-vein meets the root of the third long vein and they are of about equal length, while the posterior cross-vein is much shorter, and three times its length interior to them. Halteres have light stems and dark knobs.

Length: (female) $3 \mathrm{~mm}$. (male) $2.5 \mathrm{~mm}$.

Habitat: Rather widespread, but the first specimens were taken at Iloilo, Panay, P. I.

Taken at various times in the various places.

THE STANFORD EXPEDITION TO BRAZIL, 1911. J. C BRANNER, Director.

ACARIANS FROM BRAZIL.

By Nathan Banks, East Falls Church, Va.

The mites collected by Messrs. Mann and Baker belong to two families, Ixodidæ and Parasitidæ (Gamasidæ). Several are the same as those described from Paraguay by Berlese; the ticks are species common in Brazil; of the six species described as new, the Trachuropoda is the most remarkable. Besides these there are some immature specimens, mostly of the Parasitidæ, that cannot be named.

\section{IXODIDÆ.}

Amblyomma striatum Koch. Two from Porto Velho, Rio Madeira (Mann and Baker).

Amblyomma geayi Neum. One from Abuná, Rio Madeira, Brazil (Mann and Baker).

Margaropus annulatus Say. Several from Porto Velho, Rio Madeira, Brazil, (Mann and Baker).

Parasitida.

Megalololaps høros Berl. Several from Independencia, Parahyba, on Copris (Mann). 

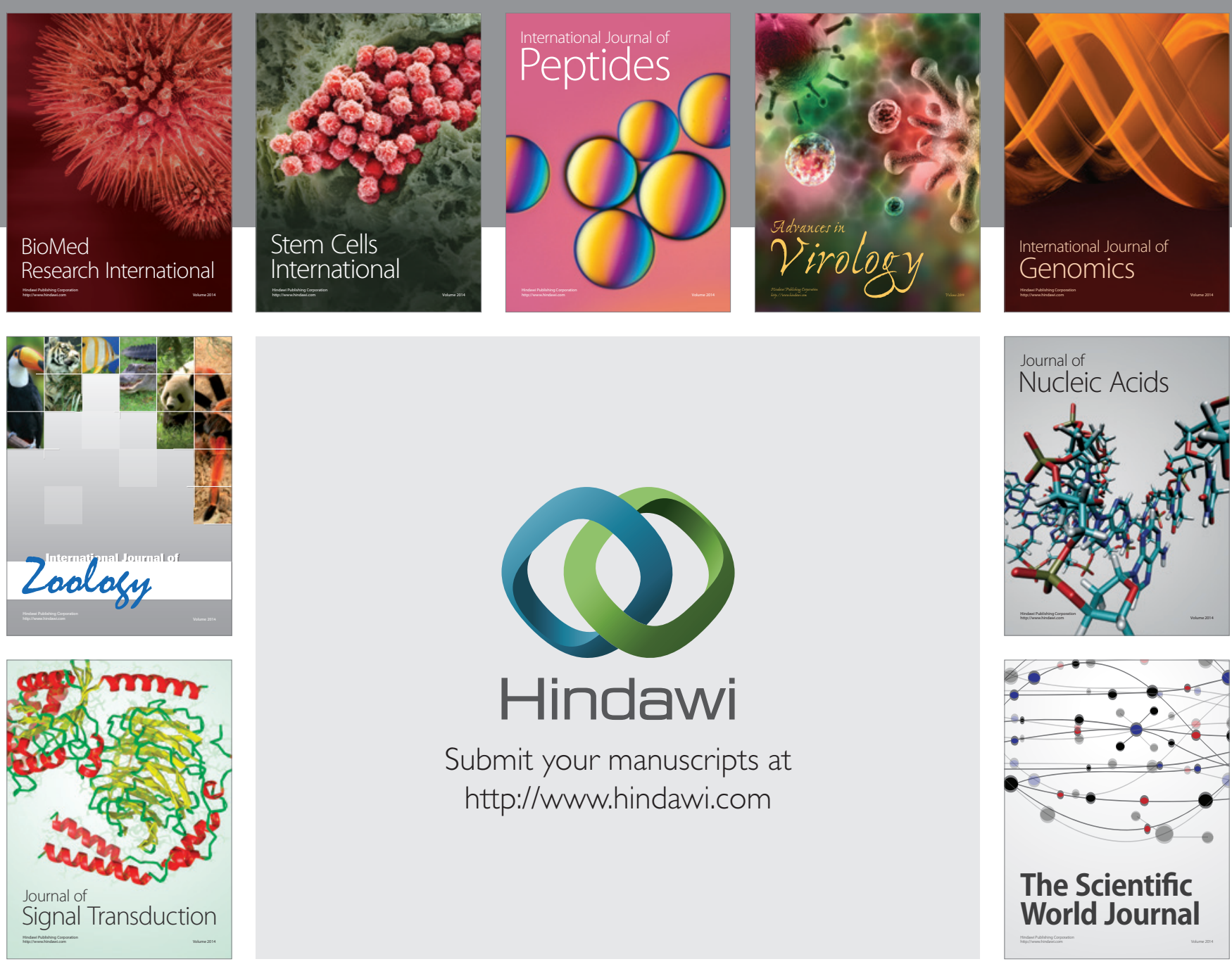

Submit your manuscripts at

http://www.hindawi.com
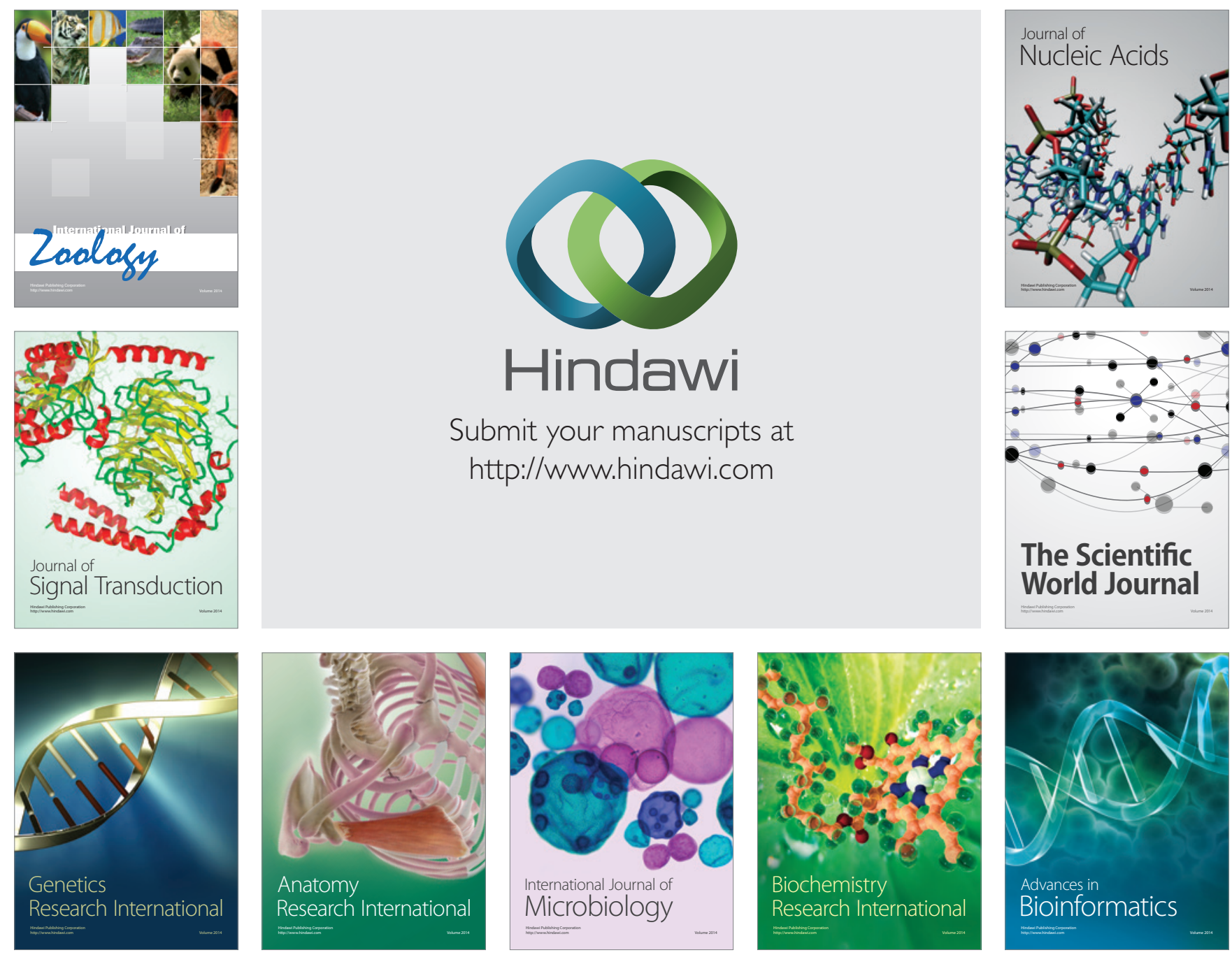

The Scientific World Journal
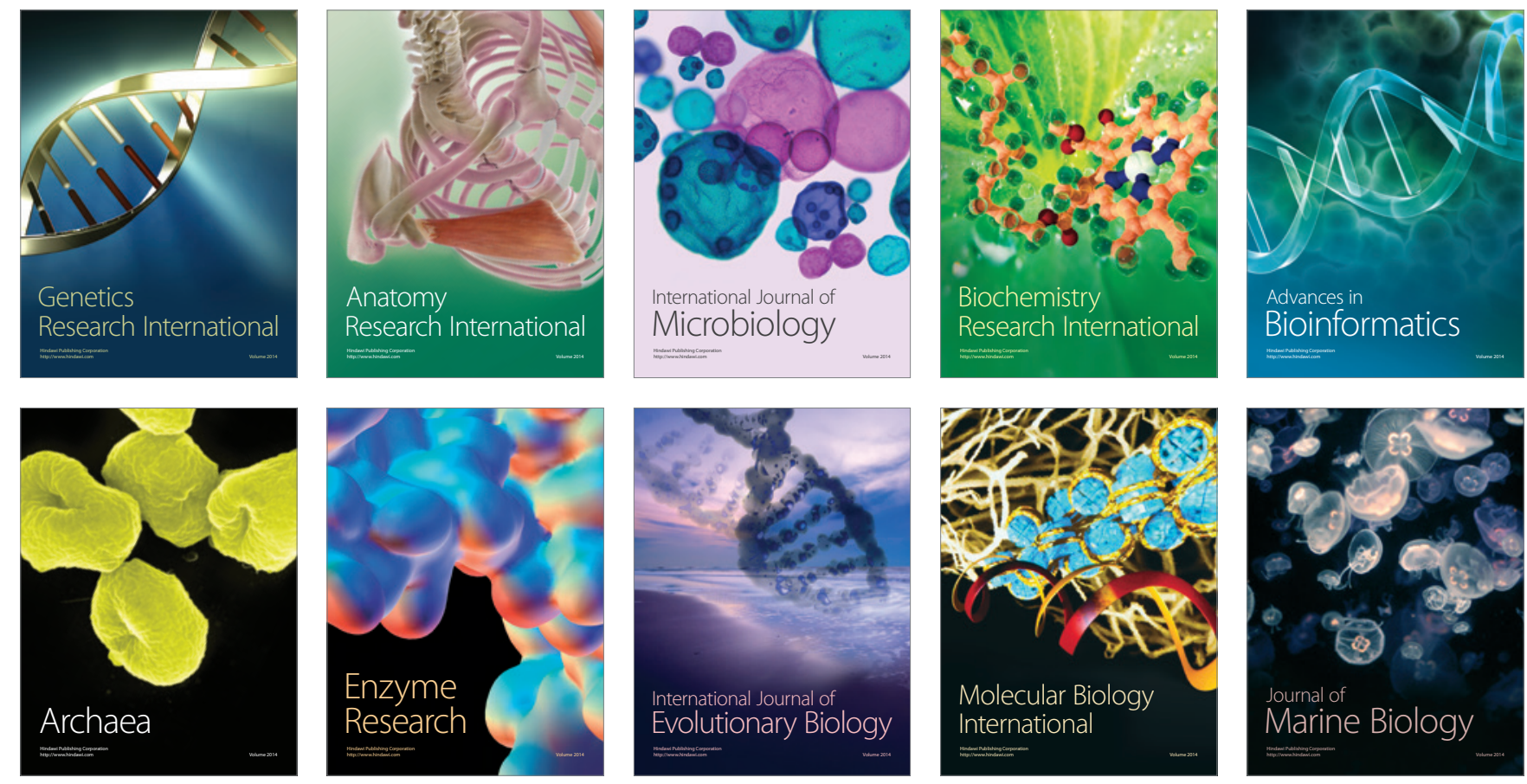